\title{
Analisis Bentuk Perubahan Makna dalam Takarir Instagram Mendikbud Nadiem Makarim Januari 2021 (Suatu Kajian Semantik)
}

\author{
Indriani Suharyan \\ Program Studi Pendidikan Bahasa Indonesia \\ Fakultas Keguruan dan Ilmu Pendidikan Universitas Siliwangi \\ indrianisuharyan@gmail.com
}

\begin{abstract}
Abstrak
Penelitian ini bertujuan untuk mendeskripsikan jenis perubahan makna yang terjadi dalam takarir Instagram Menteri Pendidikan dan Kebudayaan Indonesia, Nadiem Makarim, beserta faktor penyebab terjadinya perubahan makna tersebut. Metode yang digunakan dalam penelitian ini ialah metode deskriptif kualitatif. Metode deskriptif adalah metode penelitian yang mengacu pada kegiatan menggambarkan suatu objek dalam rangka menjawab suatu permasalahan penelitian. Penelitian kualitatif adalah jenis penelitian yang bukan hanya berfokus pada hasil atau produk, tetapi juga menekankan proses. Teknik pengumpulan data yang digunakan dalam penelitian ini ialah teknik Simak Bebas Libat Cakap (SBLC) dan teknik dokumentasi. Langkah-langkah analisis data antara lain: mengidentifikasi kata maupun frasa yang mengacu pada aspek perubahan makna; mencatat hasil identifikasi; melakukan pengumpulan dan pengolahan data; dan menarik kesimpulan. Berdasarkan penelitian ini, ditemukan 21 kata yang mengalami perubahan makna. Bentuk perubahan makna yang terjadi yaitu generalisasi berjumlah $11 \mathrm{kata}$, spesialisasi berjumlah $1 \mathrm{kata}$, eufemia berjumlah 4 kata, asosiasi berjumlah $1 \mathrm{kata}$, dan perubahan total berjumlah 4 kata. Penyebab terjadinya perubahan makna tersebut ialah karena perkembangan sosial dan budaya, perbedaan bidang pemakaian, adanya asosiasi, proses gramatikal, serta pengembangan istilah.
\end{abstract}

Kata Kunci: perubahan makna; Instagram; deskriptif kualitatif

\section{PENDAHULUAN}

Bahasa merupakan alat komunikasi manusia dalam berinteraksi. Fakta inilah yang secara fundamental membedakan manusia dengan makhluk hidup lainnya. Menurut Kamus Besar Bahasa Indonesia Edisi V, bahasa didefinisikan sebagai sistem lambang bunyi yang arbitrer, yang digunakan oleh anggota suatu masyarakat untuk bekerja sama, berinteraksi, dan mengidentifikasi diri. Sementara itu, Moriyama dan Budiman (2010: 2) berpendapat bahwa bahasa adalah alat komunikasi yang digunakan oleh manusia. Setiap penutur bahasa 
mempunyai perbendaharaan kata tersendiri, cara pengungkapan gagasan yang khas, serta keterkaitan yang unik dengan bahasa itu. Boleh dikatakan, bahasa merupakan bagian dari kepribadian manusia. Seiring berkembangnya zaman, tentunya bahasa juga mengalami perubahan serta kemajuan. Hal tersebut didasarkan pada kehidupan manusia yang terus berjalan secara progresif. Deutsher (dalam Moriyama dan Budiman, 2010: 16) mengemukakan faktor penyebab terjadinya perubahan bahasa antara lain karena: sifat manusia yang cenderung menyesuaikan diri terhadap lingkungan dan dunia yang senantiasa berubah; peranan otoritas bahasa untuk memodernisasikan bahasa sesuai dengan pembaharuan teknologi dan gagasan; serta hubungan dengan bangsa lain yang menggunakan bahasa yang berbeda.

Merujuk pada perkembangan bahasa yang terjadi, maka perubahan makna memiliki pengaruh yang signifikan terhadap nilai rasa yang ditimbulkan dalam suatu wacana, baik lisan maupun tulis. Hal ini berhubungan dengan kemampuan manusia menafsirkan makna secara tepat. Artinya, dengan memahami konteks perubahan makna, maka komunikan akan dapat menafsirkan maksud komunikator melalui penyampaian bahasa yang baik dan benar. Perubahan makna merupakan salah satu kajian semantik. Surastina (2011: 5) berpendapat bahwa semantik sebagai studi tentang makna merupakan masalah pokok dalam komunikasi, karena komunikasi menjadi faktor yang penting di dalam komunitas sosial (masyarakat), semantik juga merupakan pusat studi tentang pikiran, kognisi, dan konsep-tualisasi.

Sementara itu, Suhardi (2015: 117) mengemukakan perubahan makna sebagai gejala pergantian rujukan dari simbol bunyi yang sama. Hal tersebut berarti dalam konsep perubahan makna, terjadi peralihan acuan yang digunakan saat ini dengan acuan semula. Dilihat dari praktik pemakaian bahasa, kenyataannya makna suatu kata memang tidak selalu bersifat statis, sebagaimana sifat bahasa itu sendiri yang dinamis. Kustriyono (2016) berpendapat bahwa proses perubahan makna terbagi menjadi tujuh jenis, yaitu perluasan atau generalisasi, penyempitan makna atau spesialisasi, peninggian makna atau ameliorasi, penurunan makna atau peyorasi, sinestesia, asosiasi, dan metafora. Sementara itu, Chaer (dalam Shohiburrida, 2018) mengklasifikasikan perubahan makna sebagai berikut: meluas, menyempit, perubahan total, penghalusan, pengasaran, sinestesia, dan asosiasi. Faktor penyebab terjadinya perubahan makna yang dikemukakan oleh Dewi (2009: 29-35), di antaranya: perkembangan ilmu dan teknologi; perkembangan sosial dan budaya; perbedaan bidang pemakaian; adanya asosiasi; pertukaran tanggapan indra; perbedaan tanggapan; adanya penyingkatan; proses gramatikal; serta pengembangan istilah.

Berdasarkan penjabaran di atas, penelitian ini memfokuskan pada pembahasan mengenai perubahan makna dalam takarir Instagram Menteri Pendidikan dan Kebudayaan 
Indonesia, Nadiem Makarim yang diunggah selama bulan Januari 2021. Sebagai seseorang yang memiliki tanggung jawab besar dalam membantu presiden menyelenggarakan pemerintahan negara, khususnya di bidang pendidikan dan kebudayaan, Nadiem Makarim seyogianya memberikan representatif yang positif kepada masyarakat. Representatif yang positif itu dapat diketahui salah satunya melalui penggunaan media sosial, seperti halnya Instagram. Semenjak lahirnya teknologi informasi dan internet, media sosial banyak dimanfaatkan untuk melakukan komunikasi dua arah. Berkenaan dengan hal tersebut, Alyusi (2016: 23) mengemukakan bahwa fenomena interaksi sosial online saat ini merupakan salah satu karakteristik dari masyarakat informasi.

Di zaman modern seperti sekarang, Instagram menjadi salah satu platform yang memiliki banyak pengguna, terlebih di kalangan generasi milenial. Melalui data yang dirilisnya, NapoleonCat selaku perusahaan analis Social Media Marketing yang berbasis di Polandia, mengonfirmasikan bahwa pada periode Januari-Mei 2020, pengguna Instagram di Indonesia mencapai angka 69,2 juta jiwa. Jumlah tersebut merupakan peningkatan dari bulan ke bulan. Kelompok usia produktif yang berkisar antara 18-34 tercatat mendominasi penggunaan platform ini. Faktanya, Instagram memang telah menjadi konsumsi masyarakat Indonesia, tidak hanya digunakan oleh kelompok orang biasa saja, tetapi juga public figure, termasuk artis dan pejabat pemerintah. Melihat pada realitas tersebut, informasi yang disampaikan oleh Nadiem Makarim melalui takarir Instagramnya haruslah menggunakan bahasa yang baik dan benar. Hal itu guna membentuk pemahaman yang baik terhadap pembacanya, sehingga tidak terjadi mikonsepsi.

Berdasarkan penjabaran di atas, maka penelitian ini bertujuan untuk mendeskripsikan jenis perubahan makna yang terjadi dalam takarir Instagram Menteri Pendidikan dan Kebudayaan Indonesia, Nadiem Makarim, beserta faktor penyebab terjadinya perubahan makna tersebut. Penelitian mengenai perubahan makna kata telah dilakukan sebelumnya oleh Rehulina Juniarti BR Sembiring (2013) dengan judul Perubahan Makna dalam Rubrik Politik, Sosial, dan Ekonomi pada Harian Pontianak Post. Dari penelitiannya itu, Sembiring menghasilkan temuan mengenai jenis perubahan makna dalam tiga rubrik surat kabar harian Pontianak Post, di antaranya perluasan makna, penyempitan makna, perubahan makna secara total, penghalusan makna, serta pengasaran makna. Adanya penelitian terdahulu membuat penulis melakukan penelitian yang mampu menghasilkan penemuan baru, yakni terkait perubahan makna yang terdapat dalam takarir Instagram. 


\section{METODE PENELITIAN}

Penelitian ini termasuk ke dalam penelitian kualitatif dengan menggunakan metode deskriptif. Menurut Heryadi (2010: 42), metode deskriptif adalah metode penelitian yang digunakan peneliti untuk menggambarkan suatu objek yang ada dan terjadi saat itu untuk menjawab suatu permasalahan penelitian. Dengan menggunakan metode ini, peneliti bertugas mengumpulkan data, mendeskripsikannya, menganalisisnya, sampai membuat kesimpulan sebagai jawaban terhadap masalah penelitian. Sementara itu, Rukajat (2018: 4) mengemukakan bahwa penelitian kualitatif adalah jenis penelitian yang hasilnya tidak diperoleh melalui prosedur kuantifikasi, perhitungan statistik, atau cara lain yang menggunakan ukuran angka. Selain itu, penelitian kualitatif juga bukan hanya berfokus pada hasil atau produk, tetapi juga menekankan pada proses.

Sumber data penelitian ini ialah takarir Instagram Menteri Pendidikan dan Kebudayaan Indonesia, Nadiem Makarim, yang diunggah selama bulan Januari 2021. Data yang digunakan dalam penelitian ini berupa kata-kata dalam takarir Instagram Nadiem Makarim yang menunjukkan adanya perubahan makna. Kemudian, teknik pengumpulan data yang digunakan dalam penelitian ini ialah teknik Simak Bebas Libat Cakap (SBLC) dan teknik dokumentasi. Gusvitasari dkk. (2020) berpendapat bahwa teknik SBLC merupakan teknik penelitian di mana peneliti tidak terlibat dalam proses penuturan serta mencatat data-data objek penelitian. Adapun langkah-langkah analisis data dalam penelitian ini antara lain: mengidentifikasi kata maupun frasa yang mengacu pada aspek perubahan makna; hasil identifikasi kemudian ditranskripsikan atau dicatat pada kartu pencatat data; melakukan pengumpulan dan pengolahan data; dan menarik kesimpulan.

\section{HASIL DAN PEMBAHASAN}

Berdasarkan hasil penelitian, ditemukan bentuk-bentuk perubahan makna dalam takarir Instagram Menteri Pendidikan dan Kebudayaan Indonesia, Nadiem Makarim. Data tersebut didapatkan dari 11 unggahan Instagram Nadiem Makarim selama bulan Januari 2021, tepatnya dari tanggal 1 Januari 2021 sampai dengan tanggal 31 Januari 2021. Data tersebut dapat dicermati melalui tabel berikut berikut. 
Tabel 1 Data Perubahan Makna

\begin{tabular}{|c|l|c|}
\hline No. & \multicolumn{1}{|c|}{ Jenis Perubahan Makna } & $\begin{array}{c}\text { Jumlah Total dalam } \\
\text { Takarir Instagram }\end{array}$ \\
\hline 1 & Generalisasi & 11 \\
\hline 2 & Spesialisasi & 1 \\
\hline 3 & Eufemia & 4 \\
\hline 4 & Asosiasi & 1 \\
\hline 5 & Perubahan Total & 4 \\
\hline \multicolumn{2}{|c|}{ Jumlah Total } & 21 \\
\hline
\end{tabular}

\section{Generalisasi (Perluasan Makna)}

Menurut Dewi (2009: 36), perluasan merupakan perubahan makna kata dari makna yang lebih khusus atau sempit ke makna yang lebih umum atau luas. Perluasan makna dapat pula diartikan sebagai perubahan makna baru menjadi lebih luas dari makna asalnya, tetapi masih berhubungan dengan makna asal itu. Chaer (dalam Sempana dkk., 2017) menjelaskan bahwa perubahan makna meluas adalah gejala yang terjadi pada sebuah kata atau leksem yang pada mulanya hanya memiliki sebuah makna, tetapi kemudian karena berbagai faktor menjadi memiliki makna-makna lain. Penulis menemukan 11 kata yang mengalami generalisasi dalam penelitian ini.

(1) Semoga anak kami senantiasa diberikan kekuatan dan bekal kebahagiaan di dalam hidupnya.

Kata bekal pada data (1) mengalami perluasan makna, sebab menurut Kamus Besar Bahasa Indonesia Edisi V, kata bekal pada dasarnya bermakna sesuatu yang disediakan (seperti makanan, uang) untuk digunakan dalam perjalanan. Umumnya makna kata bekal berlaku untuk kalimat berikut: Saya membawa bekal makan siang ke sekolah. Namun, dalam konteks kalimat di atas, kata bekal bermakna modal.

(2) Menanggapi isu intoleransi di SMKN 2 Padang. Intoleransi di satuan pendidikan tak boleh terjadi lagi. Kemendikbud telah berkoordinasi dengan pemda untuk segera mengambil tindakan tegas sesuai dengan mekanisme yang berlaku ...

Kata mengambil pada data (2) mengalami perluasan makna, sebab menurut Kamus Besar Bahasa Indonesia Edisi V, kata mengambil bermakna memegang sesuatu lalu dibawa (diangkat, digunakan, disimpan, dan sebagainya). Makna kata mengambil pada dasarnya merujuk pada nomina, seperti dalam kalimat: Aku mengambil pulpenku yang terjatuh. Namun, dalam konteks penggalan kalimat di atas, kata mengambil bermakna memberikan. 
(3) Sebagai tindakan konstruktif, @kemendikbud.ri akan segera mengeluarkan surat edaran

Kata mengeluarkan pada data (3) mengalami perluasan makna, sebab menurut Kamus Besar Bahasa Indonesia Edisi V, kata mengeluarkan pada dasarnya bermakna memindahkan sesuatu dari sebelah dalam ke sebelah luar. Namun, dalam konteks penggalan kalimat di atas, kata mengeluarkan bermakna membuat atau menerbitkan.

(4) Sebagai tindakan konstruktif, @kemendikbud.ri akan segera mengeluarkan surat edaran dan membuka hotline pengaduan untuk menghindari terulangnya pelanggaran serupa.

Kata membuka pada data (4) mengalami perluasan makna, sebab menurut Kamus Besar Bahasa Indonesia Edisi V, kata membuka pada dasarnya bermakna menjadikan tidak tertutup atau tidak bertutup (seperti menyingkap penutupnya, tudungnya, pagarnya). Namun, dalam konteks kalimat di atas, kata membuka bermakna membuat sesuatu agar dapat diakses.

(5) Kemendikbud sudah menurunkan tim untuk membantu berbagai sekolah, tenaga pendidik dan murid yang terdampak gempa.

Kata menurunkan pada data (5) mengalami perluasan makna, sebab menurut Kamus Besar Bahasa Indonesia Edisi V, kata menurunkan pada dasarnya bermakna membawa (menjadikan) turun, seperti menarik turun, mengerek ke bawah, membongkar muatan, dan sebagainya. Namun, dalam konteks kalimat di atas, kata menurunkan bermakna membentuk, yakni membentuk tim untuk terjun langsung ke lapangan.

(6) Salam hangat saya untuk tenaga pendidik dan murid di sana, semoga tetap semangat dalam situasi yang sulit dan kita dapat segera bangkit dari musibah ini.

Kata bangkit pada data (6) mengalami perluasan makna, sebab menurut Kamus Besar Bahasa Indonesia Edisi V, kata bangkit bermakna bangun (dari tidur, duduk) lalu berdiri. Makna kata bangkit pada dasarnya merujuk pada posisi yang semula rendah menjadi tinggi. Namun, dalam konteks kalimat di atas, kata bangkit bermakna semangat untuk memulai kembali.

(7) Asik banget, saya bisa ngobrol bersama @unicefinfonesia, Mbak@sophia_latjuba88 ...

Kata mbak pada data (7) mengalami perluasan makna. Mbak merupakan kata yang berasal dari bahasa Jawa, memiliki padanan dalam bahasa Indonesia yaitu kakak. Di dalam masyarakat Jawa, panggilan mbak pada dasarnya digunakan untuk menyebut saudara perempuan sekandung yang lebih tua. Namun, kata mbak juga dapat digunakan sebagai kata sapaan terhadap perempuan yang lebih tua meskipun bukan saudara kandung, seperti halnya dalam konteks penggalan kalimat di atas. 
(8) Asik banget, saya bisa ngobrol bersama @unicefindonesia, Mbak @sophia_latjuba88, dan adik-adik pelajar dari berbagai daerah tentang bagaimana mereka melakukan pembelajaran di masa pandemi.

Kata adik-adik pada data (8) mengalami perluasan makna, sebab menurut Kamus Besar Bahasa Indonesia Edisi V, kata adik pada dasarnya bermakna saudara kandung yang lebih muda (laki-laki atau perempuan). Namun, dalam konteks kalimat di atas, kata adik bermakna kata sapaan kepada laki-laki maupun perempuan yang lebih muda, yakni kata sapaan terhadap pelajar dalam jumlah yang banyak.

(9) Kita bahas kreativitas di masa PJJ, peran orangtua, dan pola pikir menghadapi tantangan berat.

Kata berat pada data (9) mengalami perluasan makna, sebab menurut Kamus Besar Bahasa Indonesia Edisi V, kata berat bermakna besar ukurannya (di antara jenisnya atau benda-benda yang serupa). Maka kata berat pada dasarnya merujuk pada nomina, seperti dalam kalimat: Meja yang berat itu berusaha ia pindahkan sendiri. Namun, dalam konteks kalimat di atas, kata berat bermakna sulit untuk dilakukan karena melebihi batas wajar.

(10) Rahmawati (Kepala SD Kartika XVII-1 Pontianak).

Kata kepala pada data (10) mengalami perluasan makna, sebab menurut Kamus Besar Bahasa Indonesia Edisi V, kata kepala pada dasarnya bermakna bagian tubuh yang di atas leher (pada manusia dan beberapa jenis hewan merupakan tempat otak, pusat jaringan saraf, dan beberapa pusat indra). Namun, dalam konteks penggalan kalimat di atas, kata kepala bermakna pemimpin atau ketua.

(11) Kami mendorong agar para guru honorer serta lulusan Pendidikan Profesi Guru melamar menjadi guru PPPK.

Kata melamar pada data (11) mengalami perluasan makna, sebab menurut Kamus Besar Bahasa Indonesia Edisi V, kata melamar pada dasarnya bermakna meminta wanita untuk dijadikan istri (bagi diri sendiri atau orang lain), dapat pula diartikan sebagai meminang. Namun, dalam konteks kalimat di atas, kata melamar bermakna meminta pekerjaan.

\section{Spesialisasi (Penyempitan Makna)}

Menurut Dewi (2009: 37), kata yang mengalami penyempitan makna adalah kata yang pada saat ini mempunyai makna lebih khusus daripada makna dahulu. Jadi, cakupan makna baru/sekarang lebih sempit daripada makna lama (semula). Penulis menemukan 1 kata yang mengalami spesialisasi dalam penelitian ini. 
(12) Ingin saya koreksi mispersepsi di media bahwa tidak ada lagi formasi CPNS untuk guru, ini salah dan tidak pernah menjadi kebijakan Kemendikbud.

Kata guru pada data (12) mengalami penyempitan makna, karena dahulu kata guru digunakan untuk menyebut orang yang memberikan ilmu, tetapi sekarang makna kata guru menjadi orang yang memberikan ilmu di suatu lembaga pendidikan (sekolah). Artinya, penyebutan kata guru hanya berlaku bagi mereka yang mengajar atau memberikan pelajaran di sekolah saja.

\section{Eufemia (Penghalusan Makna)}

Menurut Chaer (dalam Shohiburrida, 2018), penghalusan merupakan gejala yang ditampilkan kata-kata atau bentuk-bentuk yang dianggap memiliki makna yang lebih halus atau lebih sopan daripada yang akan digantikan. Kecenderungan menghaluskan makna merupakan gejala umum dalam masyarakat bahasa Indonesia. Penulis menemukan 4 kata yang mengalami eufemia dalam penelitian ini.

(13) Kemendikbud telah berkoordinasi dengan pemda untuk segera mengambil tindakan tegas sesuai dengan mekanisme yang berlaku, atas pelanggaran disiplin bagi pihak yang terlibat termasuk menerapkan kemungkinan pembebasan jabatan.

Frasa pembebasan jabatan pada data (13) mengalami penghalusan makna, sebab frasa tersebut memiliki padanan kata dengan kata pemecatan. Menurut Kamus Besar Bahasa Indonesia Edisi V, kata pemecatan bermakna proses, perbuatan memecat(kan). Dalam praktik berbahasa, frasa pembebasan jabatan tentu lebih baik dibanding kata pemecatan. Sebab frasa tersebut terdengar lebih sopan digunakan untuk menegur atau mengafirmasi pekerja yang telah melakukan kesalahan atau berbuat sewenang-wenang.

(14) Saya mendapat laporan setidaknya ada 27 sekolah yang rusak karena gempa di Sulawesi Barat.

Kata saya pada data (14) mengalami penghalusan makna, sebab kata saya terdengar lebih sopan digunakan dibanding kata gua dalam konteks kalimat di atas. Menurut Kamus Besar Bahasa Indonesia Edisi V, kata saya bermakna orang yang berbicara atau menulis (dalam ragam resmi atau biasa).

(15) Kemendikbud turut berduka atas kehilangan mereka yang berada dalam penerbangan tersebut termasuk ...

Kata kehilangan pada data (15) mengalami penghalusan makna. Menurut Kamus Besar Bahasa Indonesia Edisi V, kata kehilangan bermakna hal hilangnya sesuatu; kematian. Dalam konteks kalimat di atas, kata kehilangan tentu lebih baik dibanding kata 
kematian atau kata tewasnya. Sebab kata tersebut terdengar lebih sopan digunakan saat mengungkapkan rasa empati terhadap musibah yang menimpa seseorang.

(16) Fokus tahun ini adalah perekrutan guru honorer sampai dengan kapasitas satu juta guru (jumlah yang diangkat hanya yang lulus tes) melalui jalur PPPK.

Kata perekrutan pada data (16) mengalami penghalusan makna, sebab kata tersebut memiliki padanan kata dengan kata pengambilan. Menurut Kamus Besar Bahasa Indonesia Edisi V, kata pengambilan bermakna proses, cara, perbuatan mengambil; pemungutan; pengutipan dan sebagainya. Dalam praktik berbahasa, kata perekrutan tentu lebih baik dibanding kata pengambilan atau pemungutan. Sebab kata tersebut terdengar lebih sopan digunakan untuk mengapresiasi semangat dan komitmen calon pekerja dalam melamar pekerjaan.

\section{Asosiasi (Persamaan Makna)}

Menurut Dewi (2009: 38), asosiasi adalah hubungan antara makna lama (semula) dengan makna baru. Sementara itu, Kustriyono (2016) berpendapat bahwa asosiasi merupakan proses perubahan makna sebagai akibat persamaan sifat. Persamaan sifat ini menjadikan kata yang dimaksud memiliki makna dan maksud yang berbeda. Penulis menemukan 1 kata yang mengalami asosiasi dalam penelitian ini.

(17) Enam episode Merdeka Belajar sudah diluncurkan untuk pendidikan dasar dan menengah, pendidikan tinggi, dana BOS dan penguatan kompetensi guru.

Kata episode pada data (17) mengalami persamaan makna. Kata episode menurut Kamus Besar Bahasa Indonesia Edisi V bermakna (bagian) riwayat atau peristiwa (yang seakan-akan berdiri sendiri); seri cerita. Misalnya, dalam kalimat berikut: Cerita Raja Dus Wanta merupakan sebuah episode dalam cerita Mahabharata. Namun, dalam konteks kalimat di atas, kata episode bermakna program. Karena keenam program yang telah diluncurkan tersebut merupakan serangkaian dari kegiatan Merdeka Belajar, maka bisa dikatakan sebagai enam episode Merdeka Belajar. Hal ini berkaitan bahwa program adalah serangkaian kegiatan, sehingga kata episode berasosiasi dengan agenda.

\section{Perubahan Makna secara Total}

Menurut Dewi (2009: 40), perubahan makna total adalah berubahnya makna dari makna lama dan makna yang sangat berbeda dari makna asalnya. Chaer (dalam Sempana dkk., 2017) menjelaskan bahwa perubahan makna total adalah berubahnya sama sekali makna sebuah kata dari makna asalnya. Perubahan makna secara total dapat pula diartikan sebagai perubahan makna di mana konsep makna kata barunya tidak memiliki kaitan dengan makna 
asalnya. Penulis menemukan 4 kata yang mengalami perubahan makna secara total dalam penelitian ini.

(18) Salam hangat saya untuk tenaga pendidik dan murid di sana, semoga tetap semangat dalam situasi yang sulit dan kita dapat segera bangkit dari musibah ini.

Kata hangat pada data (18) mengalami perubahan makna secara total, sebab menurut Kamus Besar Bahasa Indonesia Edisi V, pada penggunaannya kata hangat bermakna agak panas. Sementara dalam konteks kalimat di atas, frasa salam hangat bukan berarti salam yang terasa agak panas, akan tetapi bermakna salam penuh suka cita.

(19) Duka cita mendalam atas kecelakaan yang terjadi pada penerbangan Sriwijaya Air SJ182.

Kata mendalam pada data (19) mengalami perubahan makna secara total, sebab menurut Kamus Besar Bahasa Indonesia Edisi V, kata mendalam bermakna meresap (masuk) ke dalam (seperti lebih paham, lebih mengerti). Sementara dalam konteks kalimat di atas, kata mendalam bermakna sungguh-sungguh, bukan menjorok ke arah dalam.

(20) Kami di @kemendikbud.ri juga tertantang untuk selalu bekerja keras menangani hambatan pendidikan karena pandemi ...

Kata keras pada data (20) mengalami perubahan makna secara total, sebab menurut Kamus Besar Bahasa Indonesia Edisi V, pada penggunaannya kata keras bermakna padat kuat dan tidak mudah berubah bentuknya atau tidak mudah pecah. Makna kata keras pada dasarnya merujuk pada benda padat, seperti batu, kayu, dll. Sementara dalam konteks penggalan kalimat di atas, frasa bekerja keras bukan berarti melakukan pekerjaan yang keras atau padat, melainkan bermakna bekerja dengan sungguh-sungguh.

(21) Kami mendorong agar para guru honorer serta lulusan Pendidikan Profesi Guru melamar menjadi guru PPPK.

Kata mendorong pada data (21) mengalami perubahan makna secara total, sebab menurut Kamus Besar Bahasa Indonesia Edisi V, kata mendorong bermakna menolak dari bagian belakang atau bagian depan; menyorong. Sementara dalam konteks kalimat di atas, kata mendorong bermakna mendesak atau menganjurkan melakukan sesuatu.

Terdapat cukup banyak perubahan makna dalam takarir Instagram Menteri Pendidikan dan Kebudayaan Indonesia, Nadiem Makarim yang diunggah selama bulan Januari 2021. Penyebab terjadinya perubahan makna tersebut ialah karena perkembangan sosial dan budaya, perbedaan bidang pemakaian, adanya asosiasi, proses gramatikal, serta pengembangan istilah. 
Perkembangan dalam bidang sosial kemasyarakatan dapat menyebabkan terjadinya perubahan makna. Sebuah kata yang memiliki makna 'A' karena terpengaruh perkembangan sosial dan budaya dapat menjadi 'B' dan 'C' (Dewi, 2009: 30). Dari hasil penelitian, contoh perubahan makna yang disebabkan oleh perkembangan sosial dan budaya ialah kata mbak dan adik-adik. Kedua kata tersebut memiliki bentuk yang tetap, tetapi dalam konteks kalimat yang telah dipaparkan, maknanya berubah menjadi meluas.

Perbedaan bidang pemakaian berkaitan dengan kosakata khusus yang digunakan di setiap bidang kehidupan. Menurut Dewi (2009: 31), kosa kata tersebut memiliki makna khusus. Kata-kata yang digunakan dalam bidang tertentu (dalam kehidupan dan pemakaian sehari-hari) dapat digunakan dalam bidang lain. Hal itu kemudian menyebabkan kata yang sama memiliki makna yang berbeda. Dari hasil penelitian, contoh perubahan makna yang disebabkan oleh perbedaan bidang pemakaian ialah kata melamar. Dalam bidang pekerjaan, kata melamar memiliki makna meminta pencaharian untuk mendapatkan penghasilan. Sedangkan dalam bidang pernikahan, kata melamar bermakna meminang wanita untuk dijadikan pasangan hidup (istri).

Asosiasi berkaitan dengan kata dalam konteks tertentu memiliki makna tertentu pula yang didasarkan pada adanya keterkaitan. Dewi (2009: 31) mengemukakan bahwa dalam konsep asosiasi, makna yang dimiliki kata akan berubah manakala digunakan dalam bidang lain. Namun, perubahan maknanya masih menyesuaikan makna sebelumnya. Dari hasil penelitian, contoh perubahan makna yang disebabkan oleh asosiasi ialah kata episode. Kemudian, terdapat faktor penyebab perubahan makna karena proses gramatikal. Proses gramatikal seperti afiksasi, reduplikasi, dan komposisi akan menyebabkan pula terjadinya perubahan makna. Tetapi dalam hal ini yang terjadi sebenarnya bukan perubahan makna, sebab bentuk kata itu sudah berubah sebagai hasil proses gramatikal (Pebrianto dkk., 2019). Dari hasil penelitian, contoh perubahan makna yang disebabkan oleh proses gramatikal ialah kata adik-adik. Selain mengalami generalisasi akibat perkembangan sosial budaya, kata adikadik juga mengalami perubahan makna karena proses gramatikalnya. Kata adik-adik memiliki makna jamak setelah mendapat proses reduplikasi dari kata adik yang bermakna tunggal.

Terakhir, penyebab perubahan makna karena pengembangan istilah. Menurut Dewi (2009: 35), salah satu upaya pengembangan istilah atau pembentukan istilah baru dapat dilakukan dengan memanfaatkan kosakata bahasa Indonesia yang diberi makna baru dengan proses mengubah makna tersebut. Dari hasil penelitian, contoh perubahan makna yang disebabkan oleh pengembangan istilah ialah kata-kata yang mengalami generalisasi, seperti 
kata bekal, mengambil, mengeluarkan, membuka, menurunkan, bangkit, mbak, adik-adik, berat, kepala, dan melamar.

\section{SIMPULAN}

Berdasarkan hasil penelitian, didapatkan kesimpulan yaitu ditemukan 5 jenis perubahan makna dalam takarir Instagram Menteri Pendidikan dan Kebudayaan Indonesia, Nadiem Makarim, yang diunggah selama bulan Januari 2021. Adapun kelima jenis perubahan makna tersebut ialah generalisasi ditemukan sebanyak 11 kata, spesialisasi ditemukan sebanyak 1 kata, eufemia ditemukan sebanyak 4 kata, asosiasi ditemukan sebanyak 1 kata, dan perubahan makna secara total ditemukan sebanyak 4 kata. Total keseluruhan perubahan makna yang ditemukan dalam takarir Instagram Nadiem Makarim ialah sebanyak 21 kata. Dari data tersebut, diketahui bahwa jenis perubahan makna yang paling banyak ditemukan adalah generaliasi, sementara jenis perubahan makna yang paling sedikit ditemukan ialah spesialisasi dan asosiasi. Adapun penyebab terjadinya perubahan makna tersebut di antaranya karena perkembangan sosial dan budaya, perbedaan bidang pemakaian, adanya asosiasi, proses gramatikal, serta pengembangan istilah.

Contoh perubahan makna yang disebabkan oleh perkembangan sosial dan budaya ialah kata mbak. Contoh perubahan makna yang disebabkan oleh perbedaan bidang pemakaian ialah kata melamar. Contoh perubahan makna yang disebabkan oleh adanya asosiasi ialah kata episode. Contoh perubahan makna yang disebabkan oleh proses gramatikal ialah kata adikadik. Contoh perubahan makna yang disebabkan oleh pengembangan istilah ialah kata-kata yang mengalami generalisasi seperti halnya kata kepala. 


\section{DAFTAR PUSTAKA}

Alyusi, Shiefti Dyah. 2016. Media Sosial: Interaksi, Identitas dan Modal Sosial. Jakarta: KENCANA.

Dewi, Wendi Widya Ratna. 2009. Semantik Bahasa Indonesia. Klaten: PT Intan Pariwara.

Gusvitasari, R., Wahya, W., \& Wagiati, W. 2020. Perubahan Makna Diksi Dalam Novel Orang-orang Biasa Karya Andrea Hirata (Suatu Kajian Semantik). PROCEEDINGS UNIVERSITAS PAMULANG, 1(1).

Heryadi, Dedi. 2010. Metode Penelitian Pendidikan Bahasa. Bandung: Pustaka BILLAH.

Kustriyono, Erwan. 2016. Perubahan Makna dan Faktor Penyebab Perubahan Makna Dalam Media Cetak. Jurnal Bahastra. Universitas Pekalongan, 35(2), 13-25.

Moriyama, Mikihiro, dan Manneke Budiman. 2010. Geliat Bahasa Selaras Zaman: Perubahan Bahasa-Bahasa di Indonesia Pasca-Orde Baru. Jakarta: KPG (Kepustakaan Populer Gramedia).

Pebrianto, M., Daniarsa, H. L., Hielyand, L. L. T., \& Larassati, A. 2019. Pergeseran Makna dan Kolokasi Kata Cebong Menjelang Pemilihan Umum 2019. LITE: Jurnal Bahasa, Sastra, dan Budaya, 15(2), 249-264.

Pusat Bahasa Kementerian Pendidikan Nasional. 2016. Kamus Besar Bahasa Indonesia (KBBI) Luar Jaringan (Offline).

Rukajat, Ajat. 2018. Pendekatan Penelitian Kualitatif (Qualitative Research Approach). Yogyakarta: Deepublish.

Sempana, R., Cahyono B. E. H., \& Winarsih, E. 2017. Analisis Perubahan Makna pada Bahasa yang Digunakan oleh Komentator Sepak Bola Piala Presiden 2017 Kajian Semantik. Widyabastra: Jurnal Ilmiah Pembelajaran Bahasa dan Sastra Indonesia, 5(2), 78-86.

Shohiburrida, Muhammad. 2018. Perubahan Makna pada Komentar Pertandingan Sepak Bola Timnas Indonesia U19 Piala AFF 2017. BAPALA, 5(2).

Suhardi. 2015. Dasar-dasar Ilmu Semantik. Yogyakarta: Ar-Ruzz Media.

Surastina. 2011. Pengantar Semantik \& Pragmatik. Yogyakarta: NEW ELMATERA. 